Conclusions: The study demonstrated that disease activity and structural changes consistently contributes to physical function impairment in both early and late stages of disease. Fatigue does not associate with physical function at early stages of the disease, but it increases in contribution to functional impairment as disease duration increases.

Disclosure of Interest: None declared

DOI: 10.1136/annrheumdis-2018-eular.5960

\section{AB0865 DO ASAS, ASDAS AND BASDAI THERAPY RESPONSE EVALUATION TRANSLATE THE SAME INFORMATION?}

M. Eusébio ${ }^{1}$, J.L. Gomes ${ }^{2,3}$, M. Bernardes ${ }^{4}$, P. Pinto ${ }^{5}$, H. Santos ${ }^{6}$, J. TavaresCosta $^{7}$, J. Dias ${ }^{8}$, S. Pimenta ${ }^{4}$, L. Domingues ${ }^{3}$, C. Crespo ${ }^{3}$, S. Maia ${ }^{3}$, F. Martins ${ }^{1}$, J. C. Branco ${ }^{2,3}$, F.M. Pimentel-Santos ${ }^{2,3} .^{1} S P R$, Portuguese Rheumatology Society; ${ }^{2}$ Rheumatology, HOSPITAL EGAS MONIZ - CHLO; ${ }^{3}$ CEDOC, NOVA Medical School, NOVA University of Lisbon, Lisbon; ${ }^{4}$ Rheumatology, Centro Hospitalar São João, Porto; ${ }^{5}$ Rheumatology, Centro Hospitalar Vila Nova de Gaia/Espinho, Gaia; ${ }^{6}$ Rheumatology, Instituto Português de Reumatologia, Lisbon; ${ }^{7}$ Rheumatology, Unidade Local de Saúde do Alto Minho, Ponte de Lima: ${ }^{8}$ Rheumatology, Centro Hospitalar Medio Tejo, Torres Novas, Portugal

Background: The ASAS-EULAR recommendations for the continuation of biological Disease-Modifying Anti-rheumatic Drugs (DMARD) suggest the evaluation of patients after at least 12 weeks of treatment by either the Ankylosing Spondylitis (AS) Disease Activity Score $-C$ reactive protein (ASDAS-CRP) or by the Bath AS Disease Activity Index (BASDAI). For ASDAS-CRP, a Minimal Clinical Important Difference $(\mathrm{MCID}) \geq 1.1$ is necessary, while for the total BASDAI score a $50 \%$ reduction or a change of $\geq 2.0$ points is considered clinically relevant. In clinical trials, the Assessment in Ankylosing Spondyloarthritis (ASAS) response criteria ASAS 20, ASAS 40 and ASAS 70 - are still the most frequent primary outcome measures to evaluate improvement in treatment response. However, in clinical practice the BASDAI is still routinely used.

Objectives: The aim of this work was to assess the concordance/agreement between different therapeutic outcome measures, such as the ASAS response criteria, $\triangle$ ASDAS-CRP and BASDAI 50 .

Methods: Data from 54 patients who fulfilled the modified New York criteria for AS were collected at baseline, weeks 2 and 14 post-treatment with Adalimumab. Pearson's correlation (PCCs) and the Cohen's Kappa coefficients were calculated for the three scores.

Results: A strong correlation was found between the three scores throughout the visits: $r$ ho $=-0.676$ for $\mathrm{ASDAS} / \mathrm{ASAS}$, rho $=-0.807$ for $\mathrm{ASAS} / \mathrm{BASDAl}$, and rho $=0.786$ for BASDAI/ASDAS (all PCCs with $p<0.001$ ). Additionally, when the categorization in different disease activity states and response levels was performed, PCCs revealed significant concordance/agreement between the three scores' cut-offs (see table 1).

The individuals categorised as responders, by eitheir BASDAI50 or $\triangle$ ASDAS 1.1, have shown similar clinical characteristics (Erythrocyte Sedimentation Rate, CRP, AS Quality of Life Scale and Bath AS Functional Index).

Importantly, when more stringent measures of ASAS response criteria and ASDAS were used (i.e. ASAS 70 and ASDAS $\geq 2.1$ ) the agreement with BASDAI values decreased.

Abstract AB0865 - Table 1. Summary information of the Agreement and Cohen's kappa.

\begin{tabular}{|c|c|c|c|c|}
\hline Concordance/agreement & $\mathbf{n}$ & Agreement & Cohen's K & p-value \\
\hline$\triangle A S D A S \geq 1.1$ and $A S A S 20$ & 130 & $76.92 \%$ & 0.496 & $<0.001 \dagger$ \\
\hline$\triangle A S D A S \geq 1.1$ and ASAS40 & 130 & $74.62 \%$ & 0.492 & $<0.001 \dagger$ \\
\hline$\triangle A S D A S \geq 1.1$ and $A S A S 70$ & 133 & $57.14 \%$ & 0.259 & $<0.001 \dagger$ \\
\hline$\triangle A S D A S \geq 2.1$ and $A S A S 20$ & 130 & $61.54 \%$ & 0.310 & $\angle 0.001 \dagger$ \\
\hline$\triangle A S D A S \geq 2.1$ and $A S A S 40$ & 130 & $73.08 \%$ & 0.462 & $<0.001 \dagger$ \\
\hline$\triangle A S D A S \geq 2.1$ and ASAS70 & 133 & $75.19 \%$ & 0.365 & $<0.001 \dagger$ \\
\hline BASDAI50 and ASAS20 & 150 & $82.67 \%$ & 0.638 & $\overline{<0.001 \dagger}$ \\
\hline BASDAI50 and ASAS40 & 152 & $84.21 \%$ & 0.687 & $<0.001 \dagger$ \\
\hline BASDAI50 and ASAS70 & 156 & $61.54 \%$ & 0.301 & $<0.001 \dagger$ \\
\hline BASDAI50 and $\triangle A S D A S \geq 1.1$ & 134 & $79.85 \%$ & 0.571 & $2<0.001 \dagger$ \\
\hline BASDAI50 and $\triangle$ ASDAS $\geq 2.1$ & 134 & $64.93 \%$ & 0.351 & $<0.001 \dagger$ \\
\hline
\end{tabular}

$\dagger p$-value $<0.05, n$ : number of visits

Conclusions: Our results suggest that the ASAS response criteria, $\triangle A S D A S-$ CRP and BASDAI 50 report the same clinical information. Hence, the clinician's decision should still be consistent independently of the score adopted. However, this study also highlights the importance of establishing a new and more stringent BASDAI cut-off, in alignment with ASDAS-CRP' $\geq 2.1$ and ASAS 70.

Disclosure of Interest: None declared

DOI: 10.1136/annrheumdis-2018-eular.6845

\section{AB0866 \\ ADVANCED METROLOGY IN PATIENS WITH AXIAL SPONDYLOARTHRITIS: LUMBAR OR THORACIC +LUMBAR MEASUREMENTS FOR SPINAL MOBILITY ASSESSMENT?}

I.C. Aranda-Valera ${ }^{1}$, L. Garcia-Luque ${ }^{2}$, S. Alcaraz-Clariana ${ }^{2}$, J.L. Garrido-Castro ${ }^{2}$ I. Martinez-Sanchez ${ }^{2}$, C. Gonzalez ${ }^{2}$, P. Gardiner ${ }^{3}$, P.M. Machado ${ }^{4}$, E. Collantes ${ }^{1}$, on behalf of iMaxSpA Study Group. ${ }^{1} \mathrm{HU}$ Reina Sofia, ${ }^{2} \mathrm{IMIBIC}$, Cordoba, Spain;

${ }^{3}$ WHSCT, Londonderry; ${ }^{4}$ UCL, London, UK

Background: Advanced technologies for measuring human mobility have recently emerged: motion capture, inertial measurement units (IMU) and wereable devices. Some of them are used for mobility assessment of rheumatic patients. Certain devices analyse only lumbar mobility of the patients. Axial Spondyloarthritis (axSpA) reduces spinal mobility at all levels and not only at the lumbar level. Objectives: To analyse what is the contribution of the thoracic spine to spinal mobility, and if this contribution should be taken into account in the metrological assessment of patients with axSpA.

Methods: 20 patients with axSpA and 20 age, $\mathrm{BMI}$ and sex-matched healthy subjects were recruited. An IMU sensor-based system (ViMove@) was used to measure spinal mobility. This system uses two IMU sensors and the angle between both is obtained in real time. Two tests were recorded: one with the recommended anatomical location (pelvis and L1) and another one aimed at combining lumbar +thoracic movement (pelvis and T3). Conventional metrology, radiographic structural damage (axSpA patients) and PROs were also collected.

Results: The table shows the results obtained for measuring only lumbar or lumbar +thoracic mobility, in both groups. The contribution of the thoracic spine is expressed in\% of the total movement. Pearson correlation coefficients (only for patients) with conventional metrology (BASMI), PRO questionnaires (BASDAI, BASFI and ASQoL) and structural damage (mSASSS) scores are also presented.

\begin{tabular}{|c|c|c|c|c|c|c|}
\hline & $\begin{array}{l}\text { Anterior } \\
\text { Flexion }\end{array}$ & Extension & $\begin{array}{l}\text { Lateral Left } \\
\text { Flexion }\end{array}$ & $\begin{array}{l}\text { Lateral } \\
\text { Right } \\
\text { Flexion }\end{array}$ & $\begin{array}{c}\text { Rotation } \\
\text { Left }\end{array}$ & $\begin{array}{c}\text { Rotation } \\
\text { Right }\end{array}$ \\
\hline \multicolumn{7}{|l|}{$\begin{array}{l}A x S p A \\
(n=20)\end{array}$} \\
\hline Lumbar & $40.8(17.2)$ & $8.9(7.4)$ & $22.4(9.3)$ & $19.4(8.8)$ & $\begin{array}{l}12.9 \\
(4.9)\end{array}$ & $8.2(4.9)$ \\
\hline $\begin{array}{l}\text { Lumba } \\
+ \text { Thoracic }\end{array}$ & $49.2(19.9)$ & $\begin{array}{c}18.2 \\
(12.9)\end{array}$ & $30.1(12.6)$ & $28.2(11.7)$ & $\begin{array}{c}41.6 \\
(11.5)\end{array}$ & $\begin{array}{c}35.5 \\
(12.4)\end{array}$ \\
\hline $\begin{array}{l}\text { Contribution } \\
\text { of T spine } \\
\text { Control } \\
(n=20)\end{array}$ & $17 \%$ & $50 \%$ & $26 \%$ & $33 \%$ & $68 \%$ & $76 \%$ \\
\hline Lumbar & $54.4(8.6)$ & $11.1(5.7)$ & $29.4(6.1)$ & $25.6(5.2)$ & $\begin{array}{l}15.4 \\
(5.2)\end{array}$ & $10.5(2.6)$ \\
\hline $\begin{array}{l}\text { Lumba } \\
+ \text { Thoracic }\end{array}$ & $62.6(11.9)$ & $22.2(9.6)$ & $40.4(4.6)$ & $37.9(4.4)$ & $\begin{array}{l}45.5 \\
(7.9)\end{array}$ & $37.3(8.2)$ \\
\hline $\begin{array}{l}\text { Contribution } \\
\text { of } T \text { spine }\end{array}$ & $13 \%$ & $50 \%$ & $27 \%$ & $32 \%$ & $66 \%$ & $72 \%$ \\
\hline \multicolumn{7}{|c|}{ Correlations (Lumbar/Lumbar+Thoracic) } \\
\hline BASMI & $\begin{array}{l}-0.82^{\star \star \star} \\
-0.76^{\star \star \star}\end{array}$ & $\begin{array}{c}0.50^{\star} / \\
0.71^{\star \star *}\end{array}$ & $\begin{array}{l}0.89^{* * * /} \\
0.94^{* \star *}\end{array}$ & $\begin{array}{l}-0.87^{\star \star \star} / \\
-0.89^{\star \star \star}\end{array}$ & $\begin{array}{c}0.46^{\star /} \\
0.69^{\star \star \star}\end{array}$ & $\begin{array}{l}-0.67^{\star *} / \\
-0.60^{* *}\end{array}$ \\
\hline BASDAI & $\begin{array}{c}-0.14 /- \\
0.21\end{array}$ & $\begin{array}{c}0.44 / \\
0.58^{* *}\end{array}$ & $0.30 / 0.40$ & $\begin{array}{c}-0.35 /- \\
0.45^{\star}\end{array}$ & $\begin{array}{l}0.26 / \\
0.38\end{array}$ & $\begin{array}{c}-0.49^{*} / \\
-0.71^{\star * *}\end{array}$ \\
\hline BASFI & $\begin{array}{l}-0.46^{*} / \\
-0.48^{*}\end{array}$ & $0.4 / 0.64^{\star *}$ & $\begin{array}{c}0.54^{\star /} \\
0.71^{\star \star \star}\end{array}$ & $\begin{array}{l}-0.59^{* * /} \\
-0.65^{* *}\end{array}$ & $\begin{array}{l}0.39 / \\
0.47^{\star}\end{array}$ & $\begin{array}{c}-0.67^{* *} / \\
-0.50^{*}\end{array}$ \\
\hline ASQoL & $\begin{array}{c}-0.19 /- \\
0.30\end{array}$ & $0.43 / 0.53^{*}$ & $0.39 / 0.50^{*}$ & $-0.36 /-0.41$ & $\begin{array}{l}0.26 / \\
0.33\end{array}$ & $\begin{array}{c}-0.44 /- \\
0.58^{\star *}\end{array}$ \\
\hline mSASSS & $\begin{array}{l}-0.74^{\star *} \\
-0.76^{\star *}\end{array}$ & $0.49 / 0.59$ & $0.74^{* *} / 0.56$ & $\begin{array}{l}-0.69^{*} / \\
-0.78^{* *}\end{array}$ & $\begin{array}{l}0.07 / \\
0.64^{*}\end{array}$ & $\begin{array}{c}-0.28 /- \\
0.47\end{array}$ \\
\hline
\end{tabular}

\footnotetext{
${ }^{* * *} \mathrm{p}<0.001 ;{ }^{* *} \mathrm{p}<0.01 ;{ }^{*} \mathrm{p}<0.05$.
}

Conclusions: Thoracic + Lumbar results reflect better the spinal mobility impairment of axSpA patients compared to lumbar spine assessments only. Compared to isolated lumbar spine assessment, the combined assessment showed bette correlations with conventional metrology, disease activity, physical function, health-related quality of life and spinal structural damage. Despite this, the magnitude of the differences is not enough to reject the use of a system that only considers assessment of lumbar spinal mobility.

\section{REFERENCE :}

[1] Garrido-Castro JL, et al. Assessment of spinal mobility in ankylosing spondylitis using a video-based motion capture system. Man Ther. 2012 Oct;17 (5):422-6.

Acknowledgements: This study has been funded by Foreum (Foundation for Research in Rheumatology)

Disclosure of Interest: None declared 
DOI: 10.1136/annrheumdis-2018-eular.1801

\section{AB0867 AXIAL SPONDYLOARTHRITIS POSTURE ASSESSMENT USING INERTIAL SENSORS}

J.L. Garrido-Castro ${ }^{1}$, I.C. Concha-Aranda ${ }^{2}$, P. Gardiner ${ }^{3}$, P.M. Machado ${ }^{4}$, J. Williams ${ }^{5}$, E. Collantes-Estevez ${ }^{2}$, on behalf of iMaxSpa Study Group. ${ }^{1}$ IMIBIC, ${ }^{2}$ HURS, Cordoba, Spain; ${ }^{3}$ WHSCT, Londonderry; ${ }^{4} \mathrm{UCL}$, London; ${ }^{5} \mathrm{BU}$, Bournemouth, UK

Background: Axial Spondyloarthritis (axSpA) often causes spinal deformity in patients, most commonly a flexed kyphotic posture. In the early stages a flattening of the lumbar spine or reduced lordosis may become apparent. Kyphosis of the thoracic and cervical spine is also common in severe cases, resulting in an increased 'tragus to wall distance' as clinically assessed in the BASMI score. No other measurement related to posture is routinely recorded in clinical practice. Inertial Measurement Units (IMU) is a new technology that can measure angles of anatomical regions where the sensor is located.

Objectives: To compare the spinal curvature of $\operatorname{axSpA}$ and healthy individuals to analyse if there are any significant differences between them and to correlate these with conventional assessment variables.

Methods: 20 axSpa patients and 20 healthy age, $\mathrm{BMI}$ and sex matched controls, were recruited. An IMUs system (ViMove@) was used to obtain angles at key points along the spine. Sensors were located at Pelvis, L1, T3 and occiput (figure 1). Calibrated angles for all the participants where obtained with the subject in quiet standing position looking to a point in front of her/him. PRO questionnaires (only patients) and metrology for axSpA (both groups) were also assessed. ROM for cervical and lumbar spine was also measured using IMUs.

Abstract AB0867 - Table 1

\begin{tabular}{lccccccc}
\hline & Pelvis & Lordosis & L1 & $\begin{array}{c}\text { Thor. } \\
\text { Posture }\end{array}$ & T3 & $\begin{array}{c}\text { Cerv. } \\
\text { Posture }\end{array}$ & Occiput \\
\hline axSpA & 13.9 & $23.4(8.8)$ & -9.5 & $29.1(5.1)$ & 19.6 & $26.1(3.2)$ & -6.5 \\
& $(8.5)$ & & $(4.0)$ & & $(3.8)$ & & $(3.8)$ \\
Control & 16.7 & $27.2(8.0)$ & -10.5 & $29.8(9.7)$ & 19.4 & $27.3(8.6)$ & -7.9 \\
& $(7.8)$ & & $(4.5)$ & & $(7.5)$ & & $(8.2)$ \\
Age & -0.14 & 0.05 & -0.24 & 0.33 & 0.19 & $0.44^{*}$ & $0.57^{* *}$ \\
Flex. Lat & 0.09 & -0.24 & -0.29 & 0 & -0.31 & -0.22 & $-0.47^{* *}$ \\
Tragus & $-0.37^{*}$ & $0.48^{* *}$ & 0.26 & 0.15 & $0.47^{* *}$ & 0.34 & $0.74^{* * *}$ \\
Wall & & & & & & & \\
Schöber & $0.50^{* *}$ & $-0.62^{* * *}$ & -0.28 & 0.1 & -0.16 & $-0.42^{*}$ & $-0.52^{* *}$ \\
BASMI & $-0.38^{*}$ & $0.51^{* *}$ & 0.29 & 0.09 & $0.42^{*}$ & 0.25 & $0.60^{* * *}$ \\
BASDAI & 0.06 & -0.13 & -0.2 & 0.22 & 0.09 & 0.31 & $0.41^{*}$ \\
Lumb. & $0.52^{* * *}$ & $-0.56^{* * *}$ & -0.1 & -0.03 & -0.11 & -0.09 & -0.18 \\
$\begin{array}{l}\text { Flexion } \\
\text { Lumb. }\end{array}$ & $0.30^{*}$ & $-0.39^{* *}$ & -0.2 & -0.10 & $-0.28^{*}$ & -0.21 & $-0.47^{* * *}$ \\
Lateral & & & & & & & \\
Lumb. & 0.23 & $-0.34^{*}$ & -0.27 & -0.12 & $-0.35^{* *}$ & -0.09 & $-0.41^{* *}$ \\
Rotation & & & & & & & \\
Cerv. & $0.44^{* * *}$ & $-0.46^{* * *}$ & -0.07 & -0.22 & $-0.34^{*}$ & -0.02 & $-0.32^{*}$ \\
Frontal & & & & & & & \\
Cerv. & 0.24 & -0.24 & -0.03 & -0.08 & -0.13 & -0.16 & $-0.28^{*}$ \\
Lateral & & & & & & & \\
Cerv. & $0.30^{*}$ & $-0.30^{*}$ & -0.02 & -0.10 & -0.15 & -0.2 & $-0.33^{*}$ \\
Rotation & & & & & & & \\
\hline
\end{tabular}

Results in degrees(standard deviation). Pearson correlations: * $\mathrm{p}<0.05$; ${ }^{* *} \mathrm{p}<0.01$; ${ }^{* * *} \mathrm{p}<0.001$

Results: Greater values of posture angles were obtained in healthy controls. Despite this, differences where significant $(p<0.05)$ only for Lordosis and Cervical
Posture. Lordosis angle shown a good correlation with mobility measured by Schöber and by IMU system, especially for flexion movements. Pelvis angle correlates better than $\mathrm{L} 1$ angle with all mobility variables. For cervical angles, occiput angle appears to be the best indicator for functional assessment. Thoracic angle is very similar between patients and healthy subjects. Figure represents the location of sensors with mean angles obtained by healthy group and the worst patient of axSpA group.

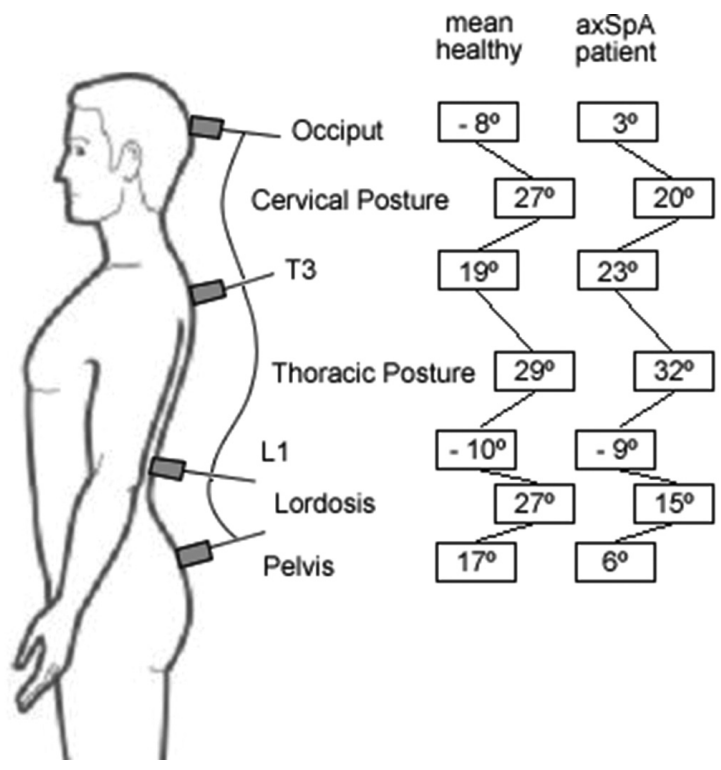

Abstract AB0867 - Figure 1

Conclusions: IMU based sensors are a useful new tool for the assessment of axSpA patients. This is the first formal evaluation of posture in axSpA and seems to be a promising tool in the functional evaluation of axSpA patients. More studies (reliability, feasibility, sensitivity to change, etc.) are needed for validating these measures.

Acknowledgements: This study has been funded by FOREUM, University of Cordoba Research Program and Junta de Andalucía (CS-S0029/2016).

Disclosure of Interest: None declared

DOI: 10.1136/annrheumdis-2018-eular.3903

\section{AB0868 LUMBAR MUSCLES STIFFNESS IN PATIENTS WITH AXIAL SPONDYLOARTHRITIS IS ALTERED IN COMPARISON WITH HEALTHY SUBJECTS}

I.C. Aranda-Valera ${ }^{1}$, S. Alcaraz-Clariana ${ }^{2}$, L. Garcia-Luque ${ }^{2}$, J.L. Garrido-Castro ${ }^{2}$, I. Martinez-Sanchez ${ }^{2}$, C. Gonzalez ${ }^{2}$, P. Gardiner ${ }^{3}$, P.M. Machado ${ }^{4}$, E. Collantes ${ }^{1}$, on behalf of iMaxSpA Study Group. ${ }^{1} \mathrm{HU}$ Reina Sofia; ${ }^{2}$ IMIBIC, Cordoba, Spain;

${ }^{3}$ WHSCT, Londonderry; ${ }^{4}$ UCL, London, UK

Background: Axial Spondyloarthritis (axSpA) patients have inflammation and/or structural damage in the lumbar spine that reduces their mobility and quality of life. The biomechanical features of axSpA have not been investigated in detail, but could prove to be a very important factor contributing to pain, stiffness and

Abstract AB0868 - Table 1

\begin{tabular}{|c|c|c|c|c|c|c|c|c|c|c|}
\hline & \multicolumn{3}{|c|}{ Measures } & \multicolumn{7}{|c|}{ Pearson correlations (axSpA/Control) } \\
\hline & AxSpa & Controls & $\begin{array}{c}p- \\
\text { values }\end{array}$ & Age & BASMI & mSASSS & LumbarFlex & LumbarExt & Lateral & Rotation \\
\hline Tone $(\mathrm{Hz})$ & $18.81(4.43)$ & $15.91(2.40)$ & $p<0.001$ & $0.60^{* *} / 0.69^{* *}$ & $0.65^{\star *}$ & $0.82^{* *}$ & $\begin{array}{c}-0.39 /- \\
0.65^{\star *}\end{array}$ & $0.12 / 0.24$ & $0.02 /-0.71^{* * *}$ & $0.11 /-0.49^{\star}$ \\
\hline Stiffness $(\mathrm{N} / \mathrm{m})$ & $\begin{array}{c}416.12 \\
(141.36)\end{array}$ & $\begin{array}{l}323.31 \\
(77.88)\end{array}$ & $p<0.001$ & $0.54^{\star} / 0.63^{*}$ & $0.63^{* *}$ & $0.77^{* *}$ & $\begin{array}{c}-0.32 /- \\
0.67^{\star \star}\end{array}$ & $0.1 / 0.19$ & $\begin{array}{c}-0.01 /- \\
0.70^{* * *}\end{array}$ & $0.08 /-0.48^{*}$ \\
\hline Decrement & $1.45(0.37)$ & $1.48(0.31)$ & N.S. & $0.3 / 0.34$ & -0.11 & -0.39 & $0.03 / 0.21$ & $0.14 / 0.02$ & $0.15 / 0.41$ & $0.31 / 0.25$ \\
\hline $\begin{array}{l}\text { Relaxation } \\
\text { (ms) }\end{array}$ & $13.73(3.55)$ & $16.98(3.35)$ & $\mathrm{p}<0.001$ & $\begin{array}{c}-0.43 /- \\
0.54^{*}\end{array}$ & $-0.57^{\star \star}$ & -0.53 & $0.28 / 0.62^{* *}$ & $-0.02 /-0.08$ & $-0.12 / 0.60^{* *}$ & $\begin{array}{c}-0.06 / \\
0.54^{\star}\end{array}$ \\
\hline Creep & $0.87(0.20)$ & $1.05(0.18)$ & $p<0.001$ & $-0.39 /-0.53$ & $-0.57^{* *}$ & -0.55 & $0.28 / 0.62^{\star *}$ & $0.03 /-0.06$ & $-0.15 / 0.63^{\star *}$ & $\begin{array}{c}-0.03 / \\
0.56^{*}\end{array}$ \\
\hline
\end{tabular}

${ }^{*} \mathrm{p}<0.05,{ }^{* *} \mathrm{p}<0.01,{ }^{* * *} \mathrm{p}<0.001$ 